\title{
Standard area diagram set for scab quantification in trilobed leaves of the sour passion fruit
}

\author{
Anne Pinheiro Costa ${ }^{1^{*}}$ (D) José Ricardo Peixoto ${ }^{1}$ \\ Luiz Eduardo Bassay Blum ${ }^{2}$ Alexandre Bosco de Oliveira ${ }^{3}$
}

${ }^{1}$ Universidade de Brasília (UNB), Faculdade de Agronomia e Medicina Veterinária, 70910-900, Brasília, DF, Brasil. E-mail: annecosta@gmail.com. ${ }^{*}$ Corresponding author.

${ }^{2}$ Universidade de Brasília (UNB), Instituto de Ciências Biológicas, Departamento de Fitopatologia, Brasília, DF, Brasil. ${ }^{3}$ Universidade Federal do Ceará (UFC), Departmento de Fitotecnia, Fortaleza, CE, Brasil.

ABSTRACT: The study aimed to develop and validate a standard area diagram set (SADs) to improve accuracy, precision, and reproducibility in the assessment of scab severity in trilobed leaves of the sour passion fruit. The SADs comprised six severity levels (1\%; 3\%; 6\%; 11\%; 21\%; and 33\%). The SADs increased the accuracy of the estimates by reducing the constant and systematic errors, and the tendency to overestimate the actual severity, limited the number of evaluators who presented this trend, in addition to increasing the bias correction factor. The inexperienced evaluators were the ones that benefited the most from the SADs use. Once the SADs was introduced, $80 \%$ and $100 \%$ evaluators gave estimates free from constant and systematic errors, respectively. The improvement in precision was verified by the increase in the coefficient of determination and Lin's concordance correlation coefficient, by reducing absolute errors and increasing the reproducibility of the estimates.

Key words: Passiflora edulis Sims, Cladosporium spp., phytopathometry.

Escala diagramática para a quantificação da verrugose em folhas trilobadas do maracujazeiro azedo

RESUMO: $O$ objetivo deste estudo foi desenvolver e validar uma escala diagramática para melhorar a acurácia, precisão e reprodutibilidade na avaliação da severidade da verrugose em folhas trilobadas do maracujazeiro azedo. A escala apresentou seis níveis de severidade $(1 ; 3 ; 6 ; 11 ; 21$ e 33\%) e aumentou a acurácia das estimativas, reduzindo os erros constantes e sistemáticos, a tendência de superestimação em relação aos valores de severidade real e o número de avaliadores que apresentavam essa tendência, além de aumentar o fator de correção do desvio. Os avaliadores inexperientes foram os mais beneficiados pela utilização da escala, sendo que $80 \%$ e $100 \%$ destes avaliadores apresentaram estimativas livres de erros constantes e sistemáticos, respectivamente, quando a escala foi empregada. $O$ aumento da precisão foi verificado pelo incremento dos coeficientes de determinação e de concordância de Lin, redução dos erros absolutos e aumento da reprodutibilidade das estimativas.

Palavras-chave: Passiflora edulis Sims, Cladosporium spp., fitopatometria.

The cultivation of the sour passion fruit (Passiflora edulis Sims) is hampered because of various diseases such as scab or cladosporiosis (Cladosporium spp.). This name is due to the wartlike surface of the fruit lesions that are caused by the fungus. The disease manifests in the growing tissues, but it can also occur in the leaves, branches, and flowers. When manifested in the photosynthesizing tissues, scab causes intense defoliation, impairs plant development, reduces productivity, and can also lead to plant death (SUSSEL, 2015).

Despite scab damage to the sour passion fruit, there are no methods to accurately and precisely quantify this disease in the field. This quantification has been performed through descriptive keys (SANTOS et al., 2008; BATISTTI et al., 2013). The biggest limitation of these keys is their high subjectivity inherent to the method, which may increase the errors of the estimates (SILVA \& MICHEREFF, 2016). According to these authors, a good method to estimate disease severity should enable the evaluator to obtain the maximum accuracy and precision in its quantification. Accuracy refers to the proximity between the estimated and actual values of disease severity, whereas precision refers to the reproducibility and repeatability associated with an estimate (NUTTER \& SCHULTZ, 1995). Therefore, standard area diagram sets (SADs) can be an efficient tool for standardizing disease severity evaluations. SADs provide a substantial reduction 
in experimental errors, with improvements in the accuracy and precision of visual estimates of disease severity (DEL PONTE et al., 2017).

Thus, this present study had the following aims: (1) to develop and validate a SADs for evaluating scab severity in trilobed leaves of the sour passion fruit; (2) to compare the accuracy, precision, and agreement of the scab severity estimates with and without the SADs use; and (3) to compare the accuracy, precision, and agreement of the estimates obtained from experienced and inexperienced evaluators.

To prepare the SADs, 50 trilobed leaves of the sour passion fruit of the cultivars BRS Gigante Amarelo and Yellow Master FB200 were collected from the Paraná Farm, Rural Nucleus Pipiripau, Planaltina, DF (47²9'56.92" S and 15³0'15.08' W, $955 \mathrm{~m}$ ) from plants that were in the fruiting stage. The processes of image capture, elaboration, validation of the SADs, and data analyses were performed as described by COSTA et al. (2018). The scanned images of the adaxial leaf surface were examined for the injured area using the IMAGE J program (SCHNEIDER et al., 2012). Disease severity (i.e., percentage of injured area) was determined by the ratio between the injured area and total area of the leaf. The SADs was elaborated considering the maximum and minimum limits of the disease. The SADs was validated by 20 evaluators (10 with previous experience and 10 without experience in disease quantification) using images of 50 leaves with symptoms at different intensities. In the first evaluation, all evaluators quantified disease severity (\%) without the SADs use. Subsequently, the evaluators were classified into four groups (G1 and G3, without previous experience; G2 and G4, with previous experience). The same images were presented to G1 and G2 who made the second evaluation without the SADs as well as to G3 and G4 who performed the evaluation using the SADs.

The accuracy and precision of the evaluators were determined using linear regression between the actual severity (independent variable) and severity estimated by the evaluator (dependent variable). The accuracy of each evaluator's estimates was determined using the $t$-test applied to the intercept of the linear regression $(a)$ to verify whether it was significantly different from 0 (without constant errors) as well as to the slope (b) to test whether it was significantly different from 1 (without systematic errors; $\mathrm{P} \leq 0.05$ ), according to NUTTER \& SCHULTZ (1995). The most accurate evaluators were those whose estimates provided linear regression equations with $a$ and $b$ values not significantly different from 0 and 1 , respectively, using the $t$-test.

The precision of the estimates was obtained by the coefficient of determination of the regression $\left(R^{2}\right)$ and by the variance of absolute errors (absolute difference between estimated and actual severity) (KRANZ, 1988). The absolute errors were compared by the $t$-test $(\mathrm{P} \leq 0.05)$. The evaluators with better linear model fitting and higher $R^{2}$ values were considered to be more precise. The criteria used in computer programs for training the evaluators in quantifying disease severity, such as Distrain (TOMERLIN \& HOWELL, 1988) and Disease Pro (NUTTER \& WORAWITLIKIT, 1989), were adopted to inspect residues. These programs classify an evaluator as excellent or good when their errors are $<5 \%$ and $<10 \%$, respectively. The reproducibility of estimates or inter-evaluator reliability was determined by the $R^{2}$ values obtained from linear regressions between the estimated severities of the same sample unit obtained by different evaluators, arranged in pairs (NUTTER \& SCHULTZ, 1995).

In addition to the linear regression between the actual and estimated severities, the accuracy and precision were determined by Lin's concordance correlation analysis $\left(\rho_{c}\right)$ that combines the measurements of accuracy $\left(C_{b}\right)$ and precision $(r)$ and is expressed as $\rho_{c}=C_{b} r$. According to this coefficient, a perfect assessment occurs when all points fall on the line of agreement, i.e., $r=1, C_{b}=1$; and consequently, $\rho_{c}=1$ (LIN, 1989).

The SADs comprised six levels of disease severity, with the lower and upper limits set at $1 \%$ and $33 \%$ of the injured leaf area, respectively (Figure 1). The values estimated by most evaluators using the SADs were closer to the actual values, indicating increased accuracy. In the first evaluation, all evaluators who presented constant and/or systematic errors overestimated the scab severity. However, this trend was more pronounced in inexperienced ones (G1 and G3; Table 1). The second evaluation by G1 and G2 was also characterized by overestimated values, with an increase in the number of estimates with constant errors among experienced evaluators (Table 1).

When the SADs was used by G3 and G4, the overestimation trend was maintained. However, the overestimated values and number of evaluators who presented this tendency reduced, as verified in previous studies (COSTA et al., 2019a, 2019b). Except for evaluator 14, all inexperienced evaluators had intercept values equal to $0(\mathrm{P} \leq 0.05)$, i.e., without constant errors. In addition, all evaluators in this group 




presented slope equal to $1(\mathrm{P} \leq 0.05)$, i.e., without systematic errors. In $\mathrm{G} 4,60 \%$ of the evaluators presented intercept values equal to $0(\mathrm{P} \leq 0.05)$ or slope equal to $1(\mathrm{P} \leq 0.05$; Table 1$)$. Consequently, the accuracy levels of all evaluators in G3 and $80 \%$ of the evaluators in G4 improved with the SADs use by reducing their constant and/or systematic errors.

The precision of estimates without the SADs use was low. Moreover, the precision increased in all evaluators with the use of the SADs, and the mean values of $R^{2}$ improved to 0.88 (G3) and 0.90 (G4). The same was not observed in the second evaluation of G1. Furthermore, the mean increments in G3 (22.2\%) and G4 (15.4\%) were higher than that observed in G2 $(9.6 \%$; Table 1$)$.

In addition, the increase in precision was confirmed by the reduction in the amplitude of absolute errors when the SADs was used $(\mathrm{P} \leq 0.05)$. The distribution of the residues from the evaluations performed without the SADs ranged from -3.0 to $+73.5(\mathrm{G} 1),-12.8$ to $+51.0(\mathrm{G} 2),-10.0$ to $+69.5(\mathrm{G} 3)$, and -5.0 to $+59.0(\mathrm{G} 4)$. In the second evaluation without the SADs, errors ranged from -15.0 to +76.7 (G1) and -9.0 to +50.0 (G2), whereas with the SADs use, errors ranged from -9.0 to $+16.3(\mathrm{G} 3)$ and -9.0 to +16.0 (G4). The means of the absolute errors in the first evaluation were $15.9(\mathrm{G} 1), 9.8(\mathrm{G} 2), 14.9$ (G3), and 9.9 (G4). In the second evaluation, G1 and G2 had mean absolute errors equal to 14.8 and 9.9, respectively, which did not differ from the values observed in the previous evaluation. However, there was a reduction in the mean of absolute errors to 2.6 (G3) and 2.1 (G4) when the SADs was used. Thus, differences were observed between the evaluations 
Table 1 - Intercept $(a)$, slope $(b)$ and coefficient of determination $\left(R^{2}\right)$ of linear regression equations calculated between actual and estimated scab (Cladosporium spp.) severity in trilobed leaves of the sour passion fruit (Passiflora edulis Sims), in evaluations performed without and with the aid of the standard area diagram set (SADs).

\begin{tabular}{|c|c|c|c|c|c|c|c|}
\hline & \multirow{3}{*}{$\begin{array}{c}\text { Evaluators } \\
\text { Inexperienced }\end{array}$} & \multicolumn{3}{|c|}{--------------------------Evaluation 1------------------------ } & \multicolumn{3}{|c|}{---------------------------Evaluation 2------------------------ } \\
\hline \multirow{8}{*}{ G1 } & & \multicolumn{3}{|c|}{ 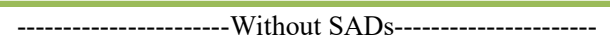 } & \multicolumn{3}{|c|}{ 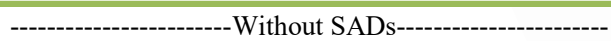 } \\
\hline & & $a$ & $b$ & $R^{2}$ & $a$ & $b$ & $R^{2}$ \\
\hline & 1 & $18.01^{*}$ & $2.20^{*}$ & 0.65 & $7.30^{*}$ & $2.09^{*}$ & 0.76 \\
\hline & 2 & $7.17^{*}$ & $1.44^{*}$ & 0.79 & $6.80^{*}$ & $1.63^{*}$ & 0.91 \\
\hline & 3 & $2.94^{*}$ & 1.01 & 0.80 & $6.29^{*}$ & $0.69^{*}$ & 0.50 \\
\hline & 4 & $6.88^{*}$ & $3.00^{*}$ & 0.69 & $11.01^{*}$ & $3.19^{*}$ & 0.72 \\
\hline & 5 & 0.79 & $1.72^{*}$ & 0.65 & -2.09 & 1.26 & 0.58 \\
\hline & Mean & 7.16 & 1.87 & 0.72 & 5.86 & 1.77 & 0.69 \\
\hline \multirow{7}{*}{$\mathrm{G} 2$} & Experienced & \multicolumn{3}{|c|}{-----------------------Without SADs----------------------- } & \multicolumn{3}{|c|}{-------------------------Without SADs----------------------- } \\
\hline & 6 & -2.63 & 0.91 & 0.55 & $-2.12^{*}$ & 1.06 & 0.85 \\
\hline & 7 & 5.68 & $2.15^{*}$ & 0.58 & $7.62^{*}$ & $1.95^{*}$ & 0.76 \\
\hline & 8 & $8.71^{*}$ & $1.38^{*}$ & 0.78 & $9.01^{*}$ & $1.38^{*}$ & 0.75 \\
\hline & 9 & 0.73 & $1.88^{*}$ & 0.86 & $3.26^{*}$ & $2.12^{*}$ & 0.85 \\
\hline & 10 & $3.86^{*}$ & 1.01 & 0.86 & 0.49 & 0.96 & 0.77 \\
\hline & Mean & 3.27 & 1.47 & 0.73 & 3.65 & 1.49 & 0.80 \\
\hline \multirow{7}{*}{ G3 } & Inexperienced & \multicolumn{3}{|c|}{----------------------Without SADs------------------------ } & \multicolumn{3}{|c|}{----------------------------With SADs------------------------- } \\
\hline & 11 & -0.95 & $1.48^{*}$ & 0.69 & 0.74 & 0.99 & 0.94 \\
\hline & 12 & $4.40^{*}$ & $1.40^{*}$ & 0.71 & -0.07 & 0.97 & 0.88 \\
\hline & 13 & $13.04^{*}$ & $3.27^{*}$ & 0.65 & 1.04 & 1.03 & 0.84 \\
\hline & 14 & $5.76^{*}$ & $1.71^{*}$ & 0.70 & $5.99^{*}$ & 0.99 & 0.80 \\
\hline & 15 & 1.89 & $2.15^{*}$ & 0.84 & 0.53 & 0.99 & 0.94 \\
\hline & Mean & 4.83 & 2.00 & 0.72 & 1.65 & 1.00 & 0.88 \\
\hline \multirow{7}{*}{ G4 } & Experienced & ------------. & hout $\mathrm{S} A$ & ----------- & \multicolumn{3}{|c|}{--------------------------With SADs------------------------- } \\
\hline & 16 & $5.53^{*}$ & $1.62^{*}$ & 0.79 & $1.11^{*}$ & 1.02 & 0.96 \\
\hline & 17 & $5.93^{*}$ & $2.08^{*}$ & 0.80 & 0.34 & $1.17^{*}$ & 0.89 \\
\hline & 18 & 1.56 & 1.03 & 0.80 & $0.90^{*}$ & $0.83^{*}$ & 0.94 \\
\hline & 19 & $5.72^{*}$ & 1.11 & 0.77 & 0.60 & 1.08 & 0.90 \\
\hline & 20 & 3.25 & $1.89^{*}$ & 0.72 & 1.14 & 1.07 & 0.79 \\
\hline & Mean & 4.40 & 1.54 & 0.78 & 0.82 & 1.03 & 0.90 \\
\hline
\end{tabular}

${ }^{*}$ Indicates that the Null hypothesis $(a=0$ or $b=1)$ was rejected by the $t$-test $(\mathrm{P} \leq 0.05)$.

performed without and with the SADs use by the same group $(\mathrm{P} \leq 0.05)$ as well as between the second evaluations of the groups with the same type of experience $(\mathrm{P} \leq 0.05)$. These results indicated the approximation between the estimates of inexperienced and experienced evaluators, thereby helping in the standardization of evaluations.

The evaluators in G2 presented errors of higher magnitude in the second evaluation, thereby increasing the percentage of estimates with errors exceeding $10 \%(-10$ to +10$)$. Thus, $64 \%$ and $63.6 \%$ of the estimates presented errors within this range in the first and second evaluations, respectively. With the SADs use, $97.6 \%(\mathrm{G} 3)$ and $98.8 \%(\mathrm{G} 4)$ of the estimates were contained within the $10 \%$ variation, corresponding to increases of $61.6 \%(\mathrm{G} 3)$ and $58.3 \%$ (G4) compared with the first evaluation. Although similar behavior was observed in $\mathrm{G} 1$, the $4 \%$ increase in estimates with errors of up to $10 \%$ was more modest than that observed for groups using the SADs. Therefore, $52.4 \%$ of the estimates showed errors of up to $10 \%$ in the second evaluation of G1.

Evaluators whose errors are contained within the $5 \%$ range $(-5$ to +5$)$ were classified as excellent (NUTTER \& WORAWITLIKIT, 1989). Using the SADs, the percentage of estimates within this range was $82.4 \%(\mathrm{G} 3)$ and $88.8 \%(\mathrm{G} 4)$ that were higher than those identified in the second evaluation 
of G1 (30.8\%) and G2 (40.8\%). Furthermore, the SADs use increased by $123.9 \%$ (G3) and $149.4 \%$ (G4) the number of estimates with errors of up to $5 \%$, indicating better approximation between the estimated and actual values. A divergent effect was confirmed in G1 and G2, where errors of higher magnitude resulted in a reduction of $4.9 \%(\mathrm{G} 1)$ and $1.0 \%(\mathrm{G} 2)$ in the percentage of estimates with errors of up to $5 \%$.

Without the SADs use, the reproducibility of estimates of disease severity was $>80 \%$ only in $20 \%$ of the cases, whereas with the SADs use, this level was reached in $70 \%$ of the cases in both groups, i.e., the reliability of estimates among the evaluators improved. Therefore, in practice, different experiments conducted by diverse evaluators can be compared as long as they used the SADs (FISCHER et al., 2009).

Lin's correlation concordance analysis corroborated the results of the regression analysis and revealed that the estimates made by the evaluators were closer to the actual values when the SADs was used. The $C_{b}$ and $r$ values increased in all cases where the SADs were used, indicating that both the accuracy and precision of visual estimates improved. In addition, all evaluators showed improvement in the agreement values $\left(\rho_{c}\right)$ with the SADs use (Table 2). In the evaluation without the SADs, the values of $\rho_{c}$ ranged from 0.16 to 0.67 with a mean of 0.45 (G3) and from 0.36 to 0.86 with a mean of 0.56

Table 2 - Correlation between estimated and actual severities $(r)$, bias correction factor $\left(C_{b}\right)$, and Lin's concordance correlation coefficient $\left(\rho_{c}\right)$ of scab (Cladosporium spp.) in trilobed leaves of the sour passion fruit (Passiflora edulis Sims), evaluated without and with the aid of the standard area diagram set (SADs).

\begin{tabular}{|c|c|c|c|c|c|c|c|}
\hline & \multirow{3}{*}{$\begin{array}{c}\text { Evaluators } \\
\text { Inexperienced }\end{array}$} & \multicolumn{3}{|c|}{  } & \multicolumn{3}{|c|}{ 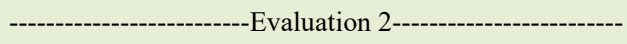 } \\
\hline \multirow{8}{*}{ G1 } & & \multicolumn{3}{|c|}{ Without SADs } & \multicolumn{3}{|c|}{----------------------------WithoutSADs------------------------- } \\
\hline & & $r$ & $C_{b}$ & $\rho_{c}$ & $r$ & $C_{b}$ & $\rho_{c}$ \\
\hline & 1 & 0.81 & 0.22 & 0.18 & 0.87 & 0.38 & 0.33 \\
\hline & 2 & 0.89 & 0.53 & 0.47 & 0.96 & 0.49 & 0.46 \\
\hline & 3 & 0.89 & 0.93 & 0.83 & 0.71 & 0.91 & 0.64 \\
\hline & 4 & 0.83 & 0.27 & 0.22 & 0.85 & 0.22 & 0.18 \\
\hline & 5 & 0.80 & 0.64 & 0.51 & 0.76 & 0.88 & 0.67 \\
\hline & Mean & 0.84 & 0.52 & 0.44 & 0.83 & 0.57 & 0.46 \\
\hline \multirow{7}{*}{$\mathrm{G} 2$} & Experienced & \multicolumn{3}{|c|}{-------------------Without SADs-------------------- } & \multicolumn{3}{|c|}{--------------------------'Without SADs----------------------- } \\
\hline & 6 & 0.74 & 0.90 & 0.66 & 0.92 & 0.97 & 0.89 \\
\hline & 7 & 0.76 & 0.39 & 0.30 & 0.87 & 0.39 & 0.34 \\
\hline & 8 & 0.89 & 0.49 & 0.44 & 0.87 & 0.49 & 0.42 \\
\hline & 9 & 0.93 & 0.60 & 0.56 & 0.92 & 0.46 & 0.42 \\
\hline & 10 & 0.93 & 0.88 & 0.82 & 0.88 & 1.00 & 0.87 \\
\hline & Mean & 0.85 & 0.65 & 0.56 & 0.89 & 0.66 & 0.59 \\
\hline \multirow{7}{*}{ G3 } & Inexperienced & \multicolumn{3}{|c|}{ 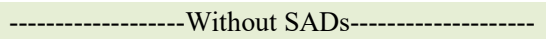 } & \multicolumn{3}{|c|}{---------------------------With SADs------------------------- } \\
\hline & 11 & 0.83 & 0.80 & 0.67 & 0.97 & 1.00 & 0.96 \\
\hline & 12 & 0.84 & 0.66 & 0.56 & 0.94 & 1.00 & 0.94 \\
\hline & 13 & 0.81 & 0.20 & 0.16 & 0.92 & 0.98 & 0.90 \\
\hline & 14 & 0.84 & 0.50 & 0.42 & 0.88 & 0.77 & 0.68 \\
\hline & 15 & 0.92 & 0.48 & 0.44 & 0.97 & 1.00 & 0.97 \\
\hline & Mean & 0.85 & 0.53 & 0.45 & 0.94 & 0.95 & 0.89 \\
\hline \multirow{7}{*}{ G4 } & Experienced & \multicolumn{3}{|c|}{-------------------Without SADs------------------- } & \multicolumn{3}{|c|}{---------------------------With SADs--------------------------- } \\
\hline & 16 & 0.89 & 0.53 & 0.48 & 0.98 & 0.99 & 0.96 \\
\hline & 17 & 0.90 & 0.41 & 0.36 & 0.94 & 0.95 & 0.89 \\
\hline & 18 & 0.90 & 0.96 & 0.86 & 0.97 & 0.98 & 0.95 \\
\hline & 19 & 0.88 & 0.73 & 0.64 & 0.95 & 0.98 & 0.93 \\
\hline & 20 & 0.85 & 0.52 & 0.44 & 0.89 & 0.96 & 0.85 \\
\hline & Mean & 0.88 & 0.63 & 0.56 & 0.95 & 0.97 & 0.92 \\
\hline
\end{tabular}


(G4). However, with the SADs use, the values of $\rho_{c}$ increased ranging from 0.68 to 0.97 with a mean of 0.89 (G3) and from 0.85 to 0.96 with a mean of 0.92 (G4; Table 2). Nevertheless, such sharp increments were not observed in any of the three parameters of the groups that performed double evaluation without the SADs. These results revealed the relevance of the SADs in estimating scab severity, even by experienced evaluators.

Thus, the validation of the SADs by linear regression, analysis of absolute errors, and Lin's coefficient of concordance produced similar results in terms of the performance of the evaluators. These methods showed an improvement in the accuracy and precision of estimates, corroborating studies that report the relevance of the SADs as tools to standardize visual estimates of disease severity and to train inexperienced and experienced evaluators alike (DEL PONTE et al., 2017). This also can be applied to the passion fruit crop (FISCHER et al., 2009; COSTA et al., 2018; MONZANI et al., 2018; COSTA et al., 2019a, 2019b, 2019c). The use of the SADs resulted in a reduction of the constant and systematic errors, which are components of accuracy. In addition, the precision based on the coefficient of determination, correlation coefficient, and the absolute errors, as well as the reliability of estimates between the pairs of evaluators improved with the use of the SADs.

\section{ACKNOWLEDGEMENTS}

This study was financed, in part, by the Coordenação de Aperfeiçoamento de Pessoal de Nível Superior-Brasil(CAPES)Finance Code 001. The authors acknowledge the evaluators for their contribution to the SADs validation. The authors also thank Dr. Ildeu Soares Martins and Dr. Michelle Souza Vilela for their guidance with the statistical analyses.

\section{DECLARATION OF CONFLICT OF} INTEREST

The authors declare no conflict of interest. The founding sponsors had no role in the design of the study; in the collection, analyses, or interpretation of data; in the writing of the manuscript, and in the decision to publish the results.

\section{AUTHORS' CONTRIBUTION}

The authors also contributed to the design and writing of the article.

\section{REFERENCES}

BATISTTI, M. et al. Resistência à verrugose de cultivares de maracujazeiro amarelo sobdiferentes métodos de inoculação. Enciclopédia Biosfera, v.9, n.16, p.2710-2720, 2013. Available from: $\quad<$ http://www.conhecer.org.br/enciclop/2013a/agrarias/ resistencia $\% 20 a \% 20$ verrugose.pdf $>$. Accessed: Oct. 01, 2019.

COSTA, A. P. et al. Standard area diagram set for bacterial spot assessment in fruits of yellow passion fruit. Revista Brasileira de Fruticultura, v.40, n.6, e-039, 2018. Available from: <http:// www.scielo.br/pdf/rbf/v40n6/0100-2945-rbf-40-6-e-039.pdf>. Accessed: Nov. 17, 2018. doi: 10.1590/0100-29452018039.

COSTA, A. P. et al. Standard area diagram set for bacterial spot quantification in entire-margined leaves of sour passion fruit. Journal of Agricultural Sciences, v.11, n.9, p.30-40, 2019c. Available from: $<$ http://www.ccsenet.org/journal/index.php/jas/ article/view/0/39721>. Accessed: Oct. 04, 2019. doi: 10.5539/jas. $\mathrm{v} 11 \mathrm{n} 9 \mathrm{p} 30$.

COSTA, A. P. et al. Standard area diagram set for quantification of septoriosis in fruit of sour passion fruit. Revista Brasileira de Ciências Agrárias, v.14, n.2, e5637, 2019b. Available from: $\quad<$ http://www.agraria.pro.br/ojs-2.4.6/index.php?journa $1=$ agraria\&page $=$ article \&op $=$ view $\&$ path $\% 5 \mathrm{~B} \% 5 \mathrm{D}=$ agraria v14i2a5637\&path\%5B\%5D=5191>. Accessed: Oct. 04, 2019. doi:10.5039/agraria.v14i2a5637.

COSTA, A. P. et al. Standard area diagram set for scab evaluation in fruits of sour passion fruit. Journal of Agricultural Sciences, v.11, n.14, p.298-305, 2019a. Available from: <http://ccsenet.org/ journal/index.php/jas/article/view/0/40379>. Accessed: Oct. 04, 2019. doi: 10.5539/jas.v11n14p298.

DEL PONTE, E. M. et al. Standard area diagrams for aiding severity estimation: scientometrics, pathosystems, and methodological trends in the last 25 years. Phytopathology, v.107, n.10, p.11611174, 2017. Available from: <https://apsjournals.apsnet.org/doi/ pdf/10.1094/PHYTO-02-17-0069-FI>. Accessed: Oct. 01, 2019. doi: 10.1094/PHYTO-02-17-0069-FI.

FISCHER, I. H. et al. Elaboração e validação de escala diagramática para quantificação da severidade da antracnose em frutos de maracujá amarelo. Summa Phytopathologica, v.35, n.3, p.226-228, 2009. Available from: <http://www.scielo.br/pdf/ sp/v35n3/a12v35n3.pdf>. Accessed: Apr. 13, 2019. doi: 10.1590/ S0100-54052009000300012.

KRANZ, J. Measuring plant disease. In: KRANZ, J.; ROTEM, J. (Ed.). Experimental techniques in plant disease epidemiology. Heidelberg: Springer-Verlag, 1988. p. 35-50.

LIN, L. I. A concordance correlation coefficient to evaluate reproducibility. Biometrics, v.45,p.255-268, 1989. Available from: <https://www.jstor.org/stable/2532051?seq=1\#page_scan_ tab_contents $>$. Accessed: Apr. 04, 2019.

MONZANI, R. M.; SILVA, G. A.; NUTTER JR, F.; DUARTE, H. S. S. DE MIO, L. L. M. Development and validation of a standard area set diagrams to evaluate bacterial blight on yellow passion fruit leaves. Summa Phytopathologica, v.44, n.4, p.332-337, 2018. Available from: <http://www.scielo.br/pdf/sp/v44n4/0100-5405sp-44-4-0332.pdf>. Accessed: Oct. 04, 2019. doi: 10.1590/0100$5405 / 175591$.

NUTTER JR., F. W.; SCHULTZ, P. M. Improving the accuracy and precision of disease assessment: selection of methods and use of computer-aided training programs. Canadian Journal of Plant Pathology, v.17, n.2, p.174-184, 1995. Available from: <https:// 
www.tandfonline.com/doi/abs/10.1080/07060669509500709>. Accessed: Apr 06, 2019. doi: 10.1080/07060669509500709.

NUTTER, F. W.; WORAWITLIKIT, O. Disease.Pro: a computer program for evaluating and improving a person ability to assess disease proportion. Phytopathology, v.79, p.1135, 1989.

SANTOS, C. E. M. et al. Estratégias de seleção em progênies de maracujazeiro amarelo quanto ao vigor e incidência de verrugose. Revista Brasileira de Fruticultura, v.30, n.2, p.444-449, 2008. Available from: <http://www.scielo.br/pdf/rbf/v30n2/a30v30n2 pdf>. Accessed: Oct. 04, 2019.

SCHNEIDER, C. A.; RASBAND, W. S.; ELICEIRI, K. W. NIH Image to ImageJ: 25 years of image analysis. Nature Methods, v.9, p.671-675, 2012. Available from: <https://www.ncbi.nlm.nih. gov/pmc/articles/PMC5554542>. Accessed: Oct. 04, 2019.

SILVA, F. J.A.; MICHEREFF, S. J. Quantificação de fitobacterioses. In: GAMA, M. A. S. et al. Estado da Arte em Fitobacterioses Tropicais. Recife: UFRPE, 2016. p.83-106.

SUSSEL, A. A. B. Estudo da Epidemiologia da Verrugosedo-Maracujazeiro. Planaltina: Embrapa Cerrados, 2015. 33p. Boletim de Pesquisa e Desenvolvimento, 327.

TOMERLIN, J. R.; HOWELL, T. A. Distrain: a computer program for training people to estimate disease severity on cereal leaves. Plant Disease, v.72, p.455-459, 1988. 